\title{
UPAYA MENINGKATKAN HASIL BELAJAR PENDIDIKAN AGAMA ISLAM (PAI) MENGGUNAKAN METODE HYPNOTEACHING BAGI SISWA KELAS VII C SMPN 1 LIMBANGAN KABUPATEN KENDAL TAHUN 2016/2017
}

\author{
Kasan As'ari ${ }^{1}$
}

\begin{abstract}
This study aims to find out what should be done to improve the learning outcomes of Islamic Teaching subject matters (PAI) by using hypnoteaching method for students of grade VII C of State Junior High School 1 Limbangan Kendal in 2016/2017 ineven semester.

This research is a classroom action research that aims to improve the learning result of PAI in the classroom. The subject of the study were students of class VII C who had the lowest learning result. This research was conducted in three cycles. Each cycle used a model or research design Kemmis and Taggart which is consisting of four components namely planning, acting, observing, and reflecting. Data completion technique used test learning result technique, where there are two tests result of learning. Those are pre-test and post-test. The test in this research used formative test in the form of objective test, the test question manifested in multiple-choice form. Data analysis technique by comparing average result of learning test before and after action is done.

The results of this research showed that hypnoteaching method can improve PAI learning result with indicators, there is enhancement on the average PAI learning result from pre-test by 70.06 increased to 73.91 in cycle I, increased again to 76.79 in cycle II and increased again to 78.94 in cycle III. KKM achievement also increased from precycles of $36.36 \%$ to $60.61 \%$ incycle I, increased again to $72.73 \%$ incycle II and increased again to $81.82 \%$ during cycle III. From the result, there has been a significant improvement in the result of cycle III, so hypnoteaching method can be standardized into a model to improve the results of learning PAI with the following actions: 1 . Affirmation by saying yells that involved the body movement and emotion, 2 . Visualization by presenting something in the shadow alongside the members' body movement, 3. Reciprocation by peer tutoring in a group, 4. Invitation the students to be grateful for the knowledge Allah has given.
\end{abstract}

Keywords: hypnoteaching method, learning result, Islamic Teaching subjects matters

\footnotetext{
Penulis adalah Pengawas PAI SMP, SMA/SMK Kabupaten Kendal, penelitian ini dilakukan pada saat penulis masih menjadi GPAI di SMPN 1 Limbangan Kab. Kendal, namun sejak Juli 2017 Penulis telah mutasi menjadi Pengawas. HP. 085225506554, email : hasan_asy_ari@yahoo.co.id
} 


\section{ABSTRAK}

Penelitian ini bertujuan untuk mengetahui upaya apa saja yang dilakukan untuk meningkatkan hasil belajar Pendidikan Agama Islam (PAI) dengan menggunakan metode hypnoteaching bagi siswa kelas VII C Sekolah Menengah Pertama Negeri 1 Limbangan kabupaten Kendal tahun 2016/2017 pada semester genap.

Penelitian in, adalah penelitian tindakan kelas yang bertujuan untuk meningkatkan hasil belajar PAI di kelas. Subjek penelitian adalah siswa kelas VII C, yang memiliki hasil belajar terendah. Penelitian dilakukan dalam tiga siklus. Setiap siklus menggunakan model atau desain penelitian Kemmis dan Taggart yang terdiri dari empat komponen yaitu planing (perencanaan), acting (tindakan), observing (observasi), dan reflecting (refleksi). Teknik pengumpulan data menggunakan teknik tes hasil belajar, dimana ada dua tes hasil belajar yaitu pretes dan postes. Tes dalam penelitian ini menggunakan tes formatif dalam bentuk tes obyektif, soal tes diwujudkan dalam bentuk pilihan ganda. Teknik analisa data yaitu dengan membandingkan rata-rata (mean) hasil tes belajar sebelum dan sesudah tindakan dilakukan.

Hasil penelitian menunjukan bahwa metode hypnoteaching dapat meningkatkan hasil belajar PAI dengan indikator, terjadi peningkatkan ratarata hasil belajar PAI dari hasil pretes sebesar 70,06 meningkat menjadi 73,91 pada siklus I, meningkat lagi menjadi 76,79 pada siklus II dan meningkat lagi menjadi 78,94 pada siklus III. Ketercapaian KKM secara kasikal juga mengalami kenaikan dari pra siklus sebesar 36,36\% meningkat menjadi $60,61 \%$ pada siklus I, meningkat lagi menjadi $72,73 \%$ pada siklus II dan meningkat lagi menjadi $81,82 \%$ pada saat siklus III. Artinya, telah terjadi peningkatkan hasil yang signifikan pada siklus III, sehingga metode hypnoteaching dapat dibakukan menjadi sebuah model untuk meningkatkan hasil belajar PAI dengan tindakan sebagai berikut: 1. Melakukan afirmasi dengan cara mengucapkan yel-yel yang melibatkan gerakan tubuh dan emosi, 2. Melakukan visualisasi dengan cara menghadirkan sesuatu dalam alam bayangan disertai gerakan menyentuh anggota tubuh, 3. Melakukan repetisi dengan cara tutor sebaya dalam sebuah kelompok, 4. Mengajak siswa bersyukur atas ilmu yang telah diberikan Allah.

Kata kunci: metode hypnoteaching, hasil belajar, Pendidikan Agama Islam

\section{A. PENDAHULUAN}

Dalam usaha memperbaiki proses belajar mengajar, berbagai metode pembelajaran harus dipraktekan. Belajar dari kekurangan metode pembelajaran konvensional, para pakar dan pemerhati pendidikan telah 
menemukan metode pendidikan yang baru/modern, dan dianggap mampu mengatasi kelemahan atau kekurangan yang ada pada metode pembelajaran konvensional, diantaranya adalah metode Quantum Learning dan Quantun Teaching yang dikembangkan oleh Bobbi DePorter, metode NLP (Neuro Linguistic Program) yang dikembangkan oleh Ernest Wong, Accelerated Learning yang dikembangkan oleh Colin Rose dan yang terakhir adalah metode Hypnolearning dan Hypnoteaching.

Ada beberapa kendala yang biasa dihadapi oleh guru agama Islam di dalam memajukan hasil Pendidikan Agama Islam di sekolah diantaranya:

1. Pelajaran tentang Pendidikan Agama Islam (PAI) terkesan lebih banyak terfokus pada masalah teoritis yang bersifat kognitif dan amalanamalan ibadah yang praktis. Terasa belum banyak menyentuk terkait dengan bagaimana pengetahuan kognitif menjadi nilai yang perlu untuk diinternalisasikan dalam karakter peserta didik.

2. Dalam ranah metodologi pembelajaran PAI, masih terkesan konvensional dan jarang adanya inovasi.

3. Dalam pelaksanaan kegiatan PAI masih cenderung berdiri sendiri dan belum berhubungan dengan materi yang lain.

4. Pendekatan yang digunakan dalam PAI masih banyak bersifat normative, belum dibarengi dengan ilustrasi konkrit terkait dengan kehidupan sosial.

5. Guru PAI kebanyakan masih terpaku pada GBPPP mata pelajaran PAI

6. Guru PAI terlalu terpaku pada GBPP mata pelajaran PAI.

7. Guru PAI cenderung lebih banyak bernuasa spiritual, belum banyak diimbangi dengan peningkatan profesionalitas dalam keguruannya. Selain itu hubungan yang tercipta antara guru dan murid masih bersifat doktriner, belum bersifat kritis-dinamis.

Kendala-kendala tersebut juga dialami pada proses pembelajaran PAI di SMPN 1 Limbangan Kabupaten Kendal, akibatnya siswa kurang termotivasi untuk mengikuti dan mendalami pelajaran PAI. Padahal Pendidikan Agama Islam harus dipahami, dihayati dan diamalkan oleh peserta didik, karena pelajaran ini memiliki karakteristik melibatkan seluruh aspek afektif, aspek kognitif, dan aspek psikomotorik peserta didik. (Sutrisno, 2008:9)

Subyek dalam penelitian ini adalah siswa kelas VII C SMPN 1 Limbangan yang tergolong rendah. Hal tersebut bisa diidentifikasi dari adanya nilai rata-rata ulangan harian siswa yang hanya mencapai 70,06 dan baru sekitar $36,36 \%$ siswa yang sudah mencapai dan atau melampaui Kriteria Ketuntasan Minimal (KKM). Nilai rata-rata tersebut di bawah standar KKM yang telah ditetapkan sekolah, yaitu sebesar 75 untuk pelajaran PAI. Padahal untuk kelas lain, bisa mencapai rata-rata nilai yang tinggi yaitu, kelas VIIA 85, kelas VIIB 80, kelas VIID 75, kelas VIIE 80 dan kelas VIIF bisa mencapai 78. 
Peneliti berasumsi, pokok permasalahan yang paling urgen dan menjadi penyebab semua permasalahan tersebut adalah metode pembelajaran PAI yang digunakan kurang efektif, kurang menyenangkan, kurang menyentuh hati, kurang memotivasi dan kurang mengesankan peserta didik, sehingga peserta didik merasa jenuh, bosan dan tidak termotivasi untuk belajar lebih dalam tentang PAI, sehingga hasil mereka dalam pelajaran PAI juga rendah.

Berdasarkan asumsi tersebut peneliti sebagai guru akan melakukan tindakan alternatif, yaitu menggunakan metode yang menyenangkan, bisa memotivasi peserta didik dan mengesankan, sehingga bisa meningkatkan hasil belajar mereka. Metode yang dipilih peneliti yaitu metode Hypnoteaching dalam pembelajaran PAI.

Permasalahan yang akan dijawab oleh penelitian ini adalah, bagaimana upaya meningkatkan hasil belajar Pendidikan Agama Islam (PAI) siswa kelas VII C SMPN 1 Limbangan Kabupaten Kendal tahun 2016/2017 dengan menggunakan metode Hypnoteaching?

\section{B. KAJIAN PUSTAKA}

\section{Hasil Belajar}

Menurut Purwanto (2010) Hasil belajar merupakan merupakan istilah yang tersusun dari dua kata yaitu 'hasil' dan 'belajar', kata tersebut miliki arti yang berbeda. Definisi hasil menunjukan atas suatu perolehan yang diakibatkan dari aktifitas ataupun proses suatu kegiatan.

Sedangkan istilah belajar dimaknai dengan suatu kegiatan penambahan pengetahuan, selain itu ada juga yang berpendapat bahwa belajar memiliki arti sama dengan menghafal, hal tersebut dipahami karena belajar pada hakikatnya sama dengan menghafal karena orang yang belajar pasti melakukan proses menghafal. (Wasty Soemanto, 1998: 104)

Belajar bisa dimaknai juga dengan tahapan perubahan seluruh tingkah laku yang relatif menetap sebagai hasil pengalaman dan interaksi dengan lingkungan yang melibatkan proses kognitif. (Muhibbin Syah, 2009: 68)

Secara umum, menurut Muhibbin Syah (2009) ada tiga faktor yang bisa mempengaruhi belajar, yaitu (a). Faktor internal, yaitu suatu keadaan jasmani maupun rohani peserta didik yang dipengaruhi oleh faktor psikologis dan fisiologis seseorang. Faktor psikologis diantaranya intelegensi, minat, perhatian, motivasi dan bakat. (b). Faktor eksternal (yaitu faktor dari luar siswa), dimana faktor ini terdiri atas dua hal yaitu faktor sosial dan non sosial, dan (c). Faktor pendekatan belajar (approach to learning), yang termasuk faktor ini adalah strategi dan juga metode yang pergunakan oleh siswa dalam melaksanakan kegiatan pembelajaran. 


\section{Metode Hypnoteaching}

Istilah hypnoteaching berasal dari dua kata yaitu, hypno dan teaching. Kata hypno berasal dari hypnosis yang bisa diartikan sebagai sesuatu yang bis menyebabkan tidur, dan hypnotis berarti ahli hypnosis, (Muhammad Noer, 2010: 116) sedangkan "hypnosis" memiliki arti mensugesti dan "teaching" berarti mengajar. Sehingga hypnoteaching bisa diartikan sebagai menghypnosis/mensugesti siswa agar menjadi pintar dan melejitkan semua anak menjadi bintang. Hypnoteaching merupakan perpaduan pengajaran yang melibatkan pikiran sadar dan pikiran bawah sadar. Hypnoteaching juga dapat diartikan sebagai pembelajaran di bawah alam sadar, yaitu cara mengajar yang unik, kreatif sekaligus imajinatif. (Novian Triwidia Jaya, 2010: 4).

Menurut Muhammad Noer (2010) hypnoteaching adalah bagaimana mengajar dengan memberikan sugesti pada peserta didik. Jadi sasaran hypnoteaching adalah para guru/pendidik di dalam menjalankan fungsinya sebagai pendidik, sedangkan untuk para peserta didik yang belajarnya menggunakan teknik hypnosis di sebut dengan metode hypnolearning, yaitu teknik menghasilkan trance saat belajar sehingga membuat peserta didik selalu ketagihan belajar. (Farida Yunita Sari\&Mukhlis, 2011: 3)

Para guru yang menguasai hypnoteaching, bisa memprogram alam bawah sadar murid-muridnya, agar mereka menjadi murid yang selalu bisa memandang segala sesuatu hal dari sisi positifnya, percaya diri, memahami pelajaran yang diajarkan guru dan bersemangat baik. Hal ini tentu tidak mudah dan tidak bisa instan, tetapi harus dengan proses yang panjang dan dengan disiplin latihan. Guru harus bisa memprogram alam bawah sadarnya sendiri dulu, kemudian baru memprogram alam pikiran bawah sadar muridnya. (Freddy Faldi Syukur, 2010: 37)

Dalam pandangan MD. Isma Almatin (2010), menyatakan Hypnosis merupakan sebuah keadaan pikiran yang terjadi ketika fungsi analitis logis dari pikiran direduksi sehingga memungkinkan seorang individu merasuk kedalam jiwanya di bawh alam sadar (sub-conscious/unconcious), sehingga berbagai macam potensi yang tersimpan dalam diri akan bisa dimanfaatkan secara maksimal sehingga dapat meningkatkan kualitas hidup.

Menurut John Gruzelier, yang merupakan psikolog dari imperial College London menyatakan bahwa seseorang yang berada dalam kondisi terihypnosis, aktifitas dalam otaknya akan bisa meningkat, khususnya bagi otak yang memiliki pengaruh terhadap proses berpikir tingkat tinggi. Lebih Lanjut John menyebutkan bahwa dengan hypno tersebut maka manusia akan bisa melaksanakan sesuatu di luar yang dia impikan. Penerapan hypnosis ini dalam konteks pembelajaran akan bisa meningkatkan motivasi siswa, kepercayaan diri, kedisiplinan dan juga keorganisasian. (Novian Triwidia Jaya, 2010: 7) 
Hal senada diungkapkan oleh Hisyam A. Fahri sebagaimana dikutip Muhammad Noer bahwa hypnosis merupakan suatu kondisi dimana pikiran saat fungsi analisis logis dari pikiran seseorang direduksi sehingga menjadikan individu masuk de dalam kondisi bawah sadar. Asumsinya bahwa dengan mengaktifkan bagian bawah sadar siswa, akan memudahkan dalam memberikan sugesti dan memasukan materi pelajaran.

Pendapat lain menyatakan bahwa pikiran sadar seseorang berfungsi sebagai bagian rasional, kekuatan kehendak dan faktor kritis dan juga memori jangka pendek sehingga seringkali diidentikan dengan otak kiri. Menurut Novian (2010) bahwa mekanisme mekanisme pikiran manusia terdiri atas dua hal yaitu pikiran sadar dan pikiran bawah sadar. Sedangkan pikiran bawah sadar (sub conscious mind) berfungsi dalam menyimpan memori jangka panjang, emosi, kebiasaan dan intuisi, seringsekali disetarakan dengan otak kanan (right brain). Otak kanan merupakan otak intuitif yang memiliki kekuatan batiniah yang bisa mendapatkan informasi sebagai getaran kosmik. Otak kanan dianggap memiliki kekuatan mistis karena bisa menembus batas ruang dan waktu. Oleh sebab itu, seringkali otak kanan dianggap abnormal karena sulit diidentifikasi cara kerjanya. (Makoto Shichida, 2010: 2)

Untuk lebih jelasnya model psikologi mekanisme pikiran dan perilaku digambarkan sebagai berikut:

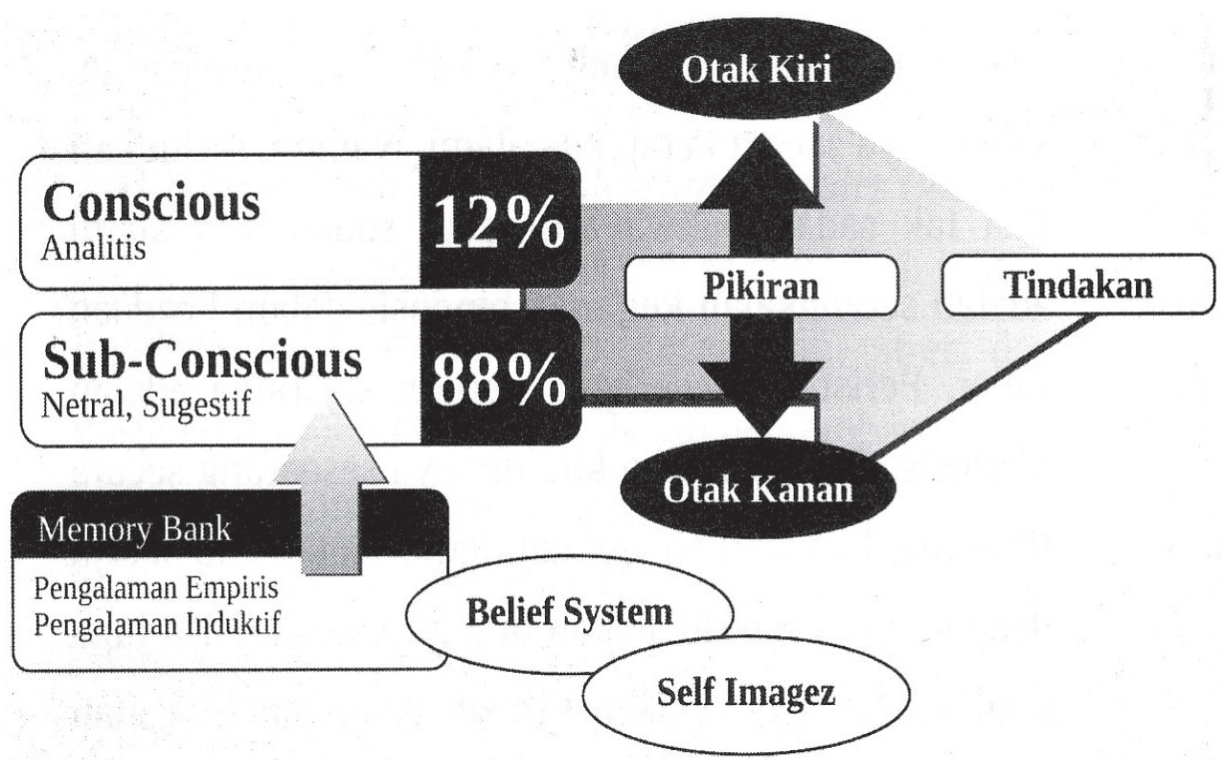

Gambar 2.1

Model psikologi mekanisme pikiran dan perilaku (diadopsi dari buku Novian Triwidia Jaya, 2010:8) 
Berdasarkan gambar tersebut dapat diketahui bahwa barometer keberhasilan dan kesuksesan seseorang ada pada sejauh mana dia bisa mengefektifkan fungsi kerja otak bawah sadar, bukan pada otak sadar. Otak bawah sadar secara teoritis menempati kedudukan sebanyak $88 \%$, sedangkan otak sadar hanya 12\% saja. (Muhammad Noer, 2010: 56) Untuk itu otak bawah sadar peserta didik harus ditanamkan nilai-nilai kebaikan, keyakinan, optimisme dan motivasi yang positif sehingga peserta didik kelak menjadi manusia yang sukses dan bahagia didalam kehidupannya. (Novian Triwidia Jaya, 2010:9)

Otak manusia terdiri atas bermilyar sel neuron. Antara neuron tersebut saling menjalin hubungan sehingga bisa menghasilkan gelombang listrik. Gelombang listrik itulah yang kemudian seringkali disebut dengan 'gelombang otak' atau brainwave. (www.terapimusik.com/terapi_gelombang otak.htm). Ada alat khusus yang digunakan untuk mengukur gelombang otak yaitu Electroencephalograph (EEG). Gelombang otak biasanya dikategorikan dalam ranah alpha, beta, delta, dan teta. Biasanya frekuensinya berkisar antara $0-30 \mathrm{~Hz}$. Masing-masing dari gelombang tersebut mimiliki karakteristik yang berbeda-beda yang dipengaruhi oleh kondisi mental dari seseorang. Untuk itu menurut Andri Hakim (2010), sebagai seorang pendidik kita harus menguasai peta gelombang pikiran seseorang yang terbagi menjadi empat kategorisasi sebagai berikut :

a) Pikiran beta

Biasanya gelombang pikiran beta berada pada frekuensi anatar 14-30 Hz. Gelombang pikiran beta berada pada frekuensi $14-30 \mathrm{~Hz}$. Seseorang yang mengalami gelombang beta bisa melaksanakan sesuatu lebih dari satu fokus. Akibatnya seseorang tersebut masih teringat dengan pekerjaan selain yang dia lakukan. Dalam kondisi ini seseorang akan mengalami kesulitan untuk berkonsentrasi karena pikirannya bercabang.

b) Pikiran alpha

Frekuensi gelombang alpha berada pada 8 - 13,9 Hz. Kondisi ini menjadikan seseorang benar-benar merasa rileks sehingga kebanyakan disebut dengan kondisi terhipnotis. Maka tidak heran jika seseorang akan mudah menyerap informasi secara maksimal karena pikirannya tidak terganggu dengan hal lain.

c) Pikiran theta

Frekuensi gelombang pikiran theta sebesar 4-7,9 Hz. Pada kondisi ini seseorang telah memasuki setengah tidur yang sering disebut dengan meditatif. Sehingga ketika dilanjutkan, seseorang tersebut akan benar-benar memasuki kondisi tertidur pulas. 
d) Pikiran delta

Frekuensi gelombang delta $0,1-3,9 \mathrm{~Hz}$. Pada kondisi ini seseorang benar-benar berada dalam kondisi tertidur pulas. Sehingga dia telah kehilangan daya kritis dan juga tidak mampu menyerap informasi yang ada di sekitarnya.

Untuk lebih jelasnya gelombang otak manusia yang diukur dengan alat EEG dalam situs http://www.terapimusik.com /terapi_gelombang_otak. $\mathrm{htm}$. dapat digambarkan dalam grafik sebagai berikut :

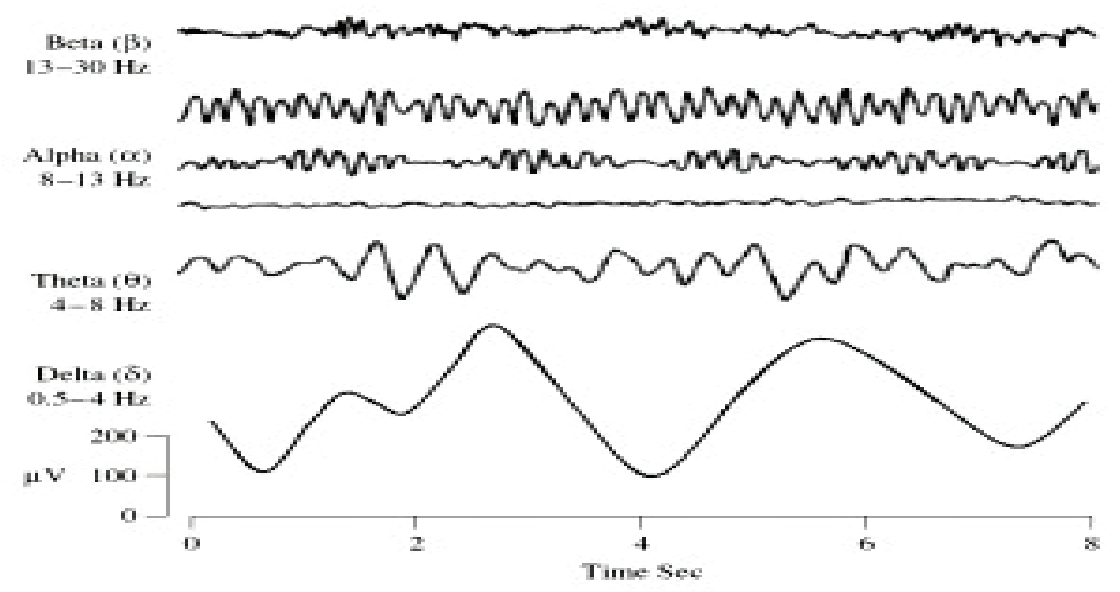

Gambar 2.2

Grafik gelombang otak dari delta hingga beta.

Selain dari 4 gelombang yang sudah disebutkan diatas, masih ada gelombang lain yaitu gelombang Gamma, hyper Gamma dan Lambda. Besaran frekuensi gelombang Gamma sebesar 40-99 Hz, gelombang hyper Gamma tepat $100 \mathrm{~Hz}$, sedangkan gelombang Lambda sebesar $200 \mathrm{~Hz}$. Menurut Dr. Jeffrey. D. Thompson, bahwa gelombang Hypergamma dan Lambda berhubungan dengan kemampuan supranatural, paranormal atau metafisika. Sedangkan gelombang Gamma bisa terjadi ketika seseorang berada pada kondisi aktifitas mental tinggi seperti ketika melakukan pertandingan, berbicara di depan umum, dsb. (http:// www.terapimusik.com/terapi_gelombang_otak.htm)

Perlu diketahui bahwa Hypnoteaching dalam realitasnya lebih banyak mengambil peran pikiran di bawah sadar. Dalam konteks ini frekeuensi gelombang yang dipakai berupa alpha dan theta yang bisa memproduksi hormone serotonin dan endorphin. Otak akan bisa menghasilkan hormone melatonin, catecholamine, dan argine-vasopressin yang dapat seseorang merasa nyaman, pikirannya bisa khusyu, serta menyebatkan ketenangan dalam hati. Hal ini sangat berbeda dengan kondisi pikiran yang sadar, ia berada pada frekuensi antara $12-25 \mathrm{~Hz}$, ia didominasi oleh logika dan otak kiri sehingga bisa menyebabkan terjadi ransangan otak mengeluarkan hormone kortisol 
dan juga nerofenifrine yang bisa menjadikan diri menjadi cemas, marah, dan juga stress (Muhammad Noer, 2010: 119) akibat buruk dari kondisi tersebut adalah beberapa penyakit mudah datang, perasaan mudah bosan, fisik dan badan cepat lelah, kepala pusing, inginnya kerumah dan cepat istirahat.

Kegiatan mengajar merupakan aktifitas untuk memasukan suatu informasi ke dalam pikiran siswa, dimana informasi ini akan diolah dalam pikiran yang sadar. Informasi tersebut bisa jadi sesuai dengan kebutuhan atau bertolak belakang dengan program yang sudah ada dalam diri. Apabila informasi tersebut sesuai maka akan dibawa dan dilanjutkan ke pikiran bawah sadar. Dalam pikiran bawah sadar inilah informasi tersebut akan bisa disimpan dan difungsikan sesuai dengan kebutuhan, dan hypnotis salah satu teknik yang tepat dan efektif untuk enghantarkan informasi ke dalam pikiran bawah sadar seseorang. (MD. Isma Almatin, 2010: 3)

Beberapa masalah yang harus diperhatikan didalam proses hypnosis di kelas menurut Muhammad Noer (2010) adalah sebagai berikut :

1) Harus mampu menciptakan kondisi yang positif. Dalam melaksanakan Hypnosis ini hendaknya guru mengajak siswa untuk melakukan kegiatan rileksasi dan santai, sehingga mereka menjadi santai. Dengan hal ini maka hypnosis akan bisa terlaksana dengan baik.

2) Harus mampu menciptakan kondisi lingkungan. Untuk mensukseskan kegiatan hypnosis maka tata setting harus mendukung, seperti kondisi yang tidak bising, ruangan yang tidak terlalu panas ataupun dingin sehingga diharapkan siswa akan merasa nyaman.

3) Pakaian dan penampilan. Ciptakan agar para siswa terkesan dulu dengan penampilan guru sebelum terkesan kepada materi pelajaran.

4) Rileksasi. Suasana hypnosis akan terlaksana jika peserta didik bisa masuk dalam kondisi santai dan rileks. Dalam kondisi sebaliknya, yaitu stress, pusing dan juga resah akan menyulitkan terlaksananya kegiatan hypnosis.

5) Memahami dunia pikiran orang lain. Belajar ilmu psikologi akan bisa memahami pikiran orang lain, karena seorang hypnosis harus bisa mengetahui pikiran orang lain.

6) Penggunaan music yang tepat bisa memperlancar terjadinya hypnosis, diantaranya music yang bernada santai dan tenang.

Penggunaan hypnoteaching dalam proses belajar mengajar memiliki kelebihan dan kekurangan. Diantara kelebihannya bisa menjadikan berkembangnya minat dan bakat peserta didik. Kegiatan belajar mengajar bisa berjalan dengan baik. Peserta didik lebih banyak mampu menyerap materi, dan lain sebagainnya. Sedangka kekurangannya antara lain belum banyak guru yang mampu menerapkannya dalam kelas. Sehingga perlu pembelajaran khusus untuk mempraktikan aktifitas ini. Selain itu kurangnya sarana dan prasarana menjadi salah satu faktor pemicu kelemahan (Davehard, 2011). 


\section{HASIL PENELITIAN DAN PEMBAHASAN \\ 1. Kondisi Awal \\ a. Deskripsi kualitatif}

Melalui observasi lapangan dapat dilihat proses pembelajaran kelas VII C SMPN 1 Limbangan sebagai berikut; hari Senin, 2 Februari 2017, jam 09.35 WIB siswa belum siap menerima pelajaran. Ketika bel masuk berbunyi, sebagian siswa masih terlihat sangat gaduh, ada yang masih nongkrong di depan ruang kelas dan sebagian masih di kantin karena jam pelajaran PAI adalah jam keempat setelah istirahat yang pertama yaitu jam 09.35 WIB sampai dengan jam 10.45 WIB .

Guru memberikan soal pretes kepada siswa, sebagai langkah awal untuk meneliti efektifitas penggunaan metode hypnoteaching.

Berdasarkan observasi lapangan sebelum melaksanakan tindakan pada siklus I, siswa nampak dalam proses pembelajaran kurang bersemangat dan kelihatan jenuh dengan pelajaran PAI, bahkan mereka nampak acuh dengan materi yang disampai oleh guru, untuk itu, guru mencoba mewawancarai beberapa siswa kelas VII C. Hal tersebut dilakukan untuk memperkuat hasil observasi dan hipotesis awal penelitian ini. Berdasarkan hasil wawancara dengan dua orang siswa adalah sebagai berikut:

a. Salsabela Riyanto

"Pelajaran PAI itu sebenarnya enak, daripada komputer dan bahasa inggris, karena gurunya masih muda, dan suaranya lantang, cuma kalau yang arab-arab itu saya susah, makanya saya sering diam kalau diajar atau saya sering main corat-coret di buku. Apalagi waktunya siang hari, jadi pingin ngantuk terus".

b. Fikri Albiansyah.

"Aku paling males belajar agama, karena sering tidak paham, ngajarnya begitu-begitu saja, kalau agama itu yang penting saya sholat jama'ah di sekolah nggak pernah bolos, saya pasti tuntas, tha wong yang agama lain saja santai, nilainya juga bagus-bagus, saya juga santai tho pak".

\section{b. Deskripsi kuantitatif}

Berdasarkan data lapangan diketahui bahwa kelas VII C secara kuantitatif berada diurutan terbawah dibandingkan kelas VII A, VII B, VII D, VII E dan kelas VII F. Hal tersebut dapat diidentifikasi dari hasil ratarata nilai ulangan harian yang ada pada guru PAI, dimana kelas VII C hanya memiliki nilai rata-rata kelas 70 sedangkan kelas VII A rata-rata kelasnya 85 , kelas VII B rata-rata kelasnya 80 , kelas VII D rata-rata kelasnya 75 , kelas VII E rata-rata kelasnya 80 dan kelas VII F rata-rata kelasnya 78. Hal ini tentu masih di bawah standar KKM (Kriterian Ketuntasan Minimal) 
yang sudah ditetapkan pihak sekolah, dimana pelajaran PAI batas KKMnya 75 .

Hal ini diperkuat kembali dengan hasil pretes yang diadakan pada hari Senin, tanggal 2 Februari 2017 dimana, kelas VII C hanya mampu mencapai nilai rata-rata kelas 70,06 dengan nilai tertinggi sebesar 90 dan nilai terendah 50. Sedangkan prosentase ketercapaian KKM secara klasikal baru 36,36. (hasil nilai pretes tiap siswa ada pada lampiran)

\section{DESKRIPSI HASIL SIKLUS}

\section{a. Siklus I}

Kegiatan pembelajaran siklus I dilaksanakan pada hari Senin, 6 Februari 2017 yang dilaksanakan di ruang laboratorium komputer. Sebelum melaksanakan tindakan guru terlebih dahulu merumuskan rencana pembelajaran, menyusun perbaikan instrumen dan menjelaskan rencana pembelajaran kepada subjek penelitian. Pelaksanaan Siklus I direncanakan dilaksanakan selama satu kali pertemuan dengan besaran alokasi waktu sebesar 2 x 40 menit.

Berdasarkan hasil postes siklus I yang dilakukan siswa didapatkan hasil sebagai berikut; (hasil postes siklus I tiap siswa ada pada lampiran). penghitungan di atas diketahui bahwa rata-rata postes siklus I adalah 73,91 dan prosentase ketercapaian KKM secara klasikal 60,61, dari kondisi tersebut diketahui bahwa dalam pekasanaan Siklus I, ternyata indicator kinerja belum bisa tercapai.

\section{b. Siklus II}

Kegiatan pembelajaran siklus II dilaksanakan pada hari Seni, 13 Februari 2017 bertempat di laboratorium komputer. Kegiatan Siklus II dilaksanakan sebanyak satu kali pertemuan dengan besaran alokasi 2 x40 menit.

Pada siklus II, peran guru sebenarnya sudah agak ringan, karena siswa sudah hapal prosesnya. Guru tidak lagi banyak mengajari siswa tentang cara duduk rileks, cara memvisualisasi dan afirmasi. Namun gangguan justru datang dari faktor eksternal, yaitu dari siswa dan panggilan guru BK yang menganggu konsentrasi siswa. Akibatnya hasil yang diperoleh pada siklus II belum maksimal. Hal ini bisa dilihat dari hasil postes, dimana siswa hanya mengalami peningkatan 3,33, dimana mean pretes 70,06 meningkat menjadi 73,39 . Sehingga bisa dikatakan bahwa penigkatan atau sumbangsih metode hypnoteaching belum signifikan untuk meningkatkan prestasi belajar PAI pada siklus II, sehingga perlu dilakukan siklus selanjutnya.

\section{c. Siklus III}

Kegiatan pembelajaran pada siklus III dilaksanakan pada hari Senin, tanggal 27 Februari 2017 yang dilaksanakan di ruang laboratorium Komputer. 
Siklus III dilakukan selama satu kali pertemuan dengan besaran alokasi waktu 2X40 menit.

Berdasarkan hasil perhitungan di siklus ke III, maka didapatkan ratarata nilai 78,94 dan prosentase ketercapaian KKM secara klasikal 81,82\%. Kesimpulannya hasil siklus III adalah signifikan dan tidak perlu diadakan siklus lanjutan karena indicator kinerja telah tercapai.

Berdasarkan hasil pengolahan data guru mengadakan refleksi pembelajaran. Adapun hasil dari refleksi adalah sebagai berikut; 1). Pelaksanaan tindakan telah berjalan sesuai dengan perencanaan. Tidak ada masalah yang menganggu jalannya perencanaan tindakan, sehingga hasilnya maksimal. Proses visualisasi, afirmasi dan repetisi peserta didik berjalan dengan lancar. Hasil yang maksimal ditandai dengan perhitungan rata-rata hasil belajar kelas VII C yang sudah mencapai 78,94 yang berarti diatas rata-rata KKM yaitu 75 . Hasil tindakan telah terbukti mampu meningkatkan prestasi belajar PAI secara berkesinambungan yang ditandai dengan peningkatan rata-rata mulai dari siklus I sampai dengan siklus III. 3). Peningkatan prestasi belajar siswa kelas VII C SMP Negeri 1 Limbangan dengan menggunakan metode hypnoteaching telah sesuai dengan indikator keberhasilan yang telah ditetapkan.

\section{Pembahasan \\ a. Antar siklus}

Dari hasil penelitian yang telah dilakukan, dapat dianalisis sebagai berikut; secara umum tampak perbedaan prestasi belajar antara sebelum tindakan dengan prestasi belajar setelah tindakan dilakukan.

Peningkatan hasil belajar pada siklus I, tidak terlalu siginifikan, karena ada banyak kendala yang ditemui pada saat pelaksanaan tindakan. Kendala tersebut lebih di dominasi dari faktor siswa yang belum terbiasa menggunakan metode hypnoteaching. Berbagai hambatan dan kendala yang terjadi pada siklus I melalui proses refleksi di analisis dan dicarikan solusinya.

Pada siklus II peningkatan hasil belajar juga belum signifikan, walaupun dibandingkan siklus I hasil rata-rata siswa meningkat. Kendala yang dihadapi pada siklus II lebih di dominasi oleh faktor eksternal, dimana hal tersebut di luar dugaan guru.

Peningkatan hasil pada siklus II, dikarenakan ada perbaikan tindakan yang dilakukan oleh pendidik sebagi hasil refleksi dari siklus I. Berdasarkan hasil diskusi dengan kolabor, maka pada siklus II di adakan perbaikan tindakan yaitu proses visualisasi tidak hanya sekedar visual dan auditori saja. Para siswa selain di ajak memvisualisasikan diri juga di ajak melakukan gerakan-gerakan (kinestetik) dan melafalkan kata kunci materi dengan halus dan lembut. Proses repetisi pada siklus II juga diadakan perbaikan, dimana pada siklus I proses repetisi dilakukan dengan cara tutor sebaya dan dilakukan oleh dua siswa, 
namun pada siklus II proses repetisi dilakukan dengan membuat beberapa kelompok kecil yang terdiri atas empat orang siswa, dimana setiap kelompok telah di tunjuk pemimpinnya. Pemimpin dalam setiap kelompok di ambil dari siswa yang memiliki kelebihan dari segi intelektual. Pemimpin ini yang nantinya sebagai kontrol bagi temannya. Proses repetisi lebih sering dilakukan karena jumlah anggota kelompok empat orang, maka otomatis setiap siswa akan mengalami pengulangan materi pelajaran selama empat kali juga.

Pada siklus III hasil belajar mulai kelihatan meningkat secara signifikan. Perbaikan tindakan yang dilakukan pada siklus III sebagai hasil dari refleksi siklus II adalah dengan memperbaiki proses visualisasi. Proses visualisasi di buat agar lebih sensual, yaitu dengan membuat singkatansingkatan dari materi. Singkatan ini dihafalkan melalui teknik melakukan gerakan dan melafalkannya dengan yel-yel. Dengan proses ini, maka indera yang bekerja lebih banyak, yaitu indera penglihatan pada saat visualisasi, indera pendengaran pada saat pengucapan yel-yel, indera perasaan pada saat mengucapkan yel-yel dengan penuh semangat disertai gerakan.

Proses repetisi pada siklus III juga mengalami perbaikan. Proses repetisi tetap menggunakan cara tutor sebaya dalam satu kelompok, namun dengan model seperti permainan kata berkait, yaitu ada siswa yang berfungsi sebagai seorang penanya dan seorang siswa menjawab pertanyaan. Hal ini dilakukan secara berantai, sehingga setiap siswa memiliki kesempatan untuk menceritakan pengalaman belajarnya kembali. Karena jumlah anggota kelompoknya ada empat orang, maka setiap siswa akan mengalami pengulangan materi empat kali.

Hasil peningkatan rata-rata setiap siklus sebagai hasil dari perbaikan tindakan yang dilakukan dalam setiap siklus dapat digambarkan dalam grafik sebagai berikut:

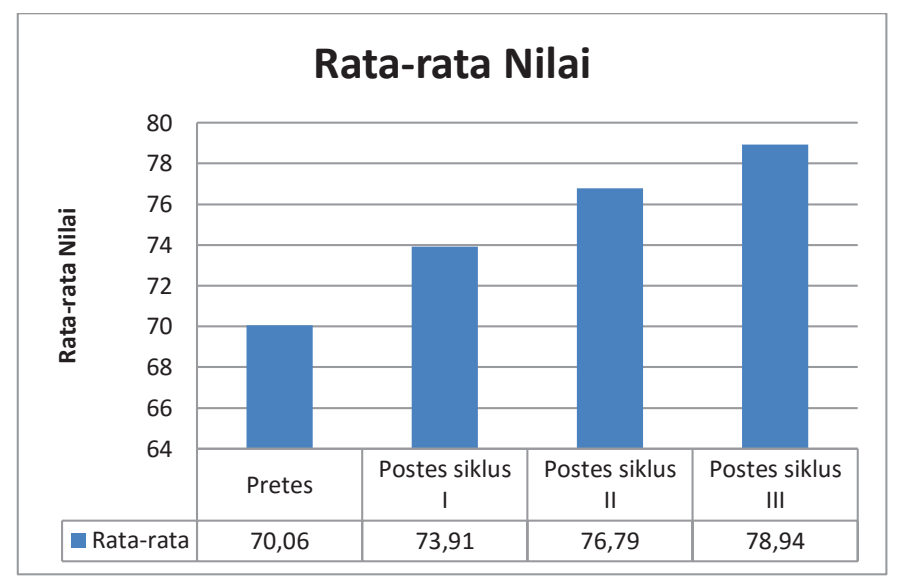

Gambar 2.1

Grafik peningkatan rata-rata tiap siklus 
Berdasarkan grafik di tersebut maka kita bisa mengetahui bahwa terjadi peningkatan rata-rata hasil belajar PAI dengan menggunakan metode hypnoteaching pada siklus I yaitu sebesar 2,85. Sedangkan pada siklus II rata-rata hasil belajar meningkat sebesar 6,73. Baru pada siklus III terjadi kenaikan yang signifikan, yaitu sebesar 8,88.

Kenaikan prosentase ketercapaian KKM secara klasikal juga terjadi, mulai dari pra tindakan yang hanya $36,36 \%$ meningkat pada siklus I menjadi $60,61 \%$, meningkat lagi menjadi $72,73 \%$ pada siklus II dan meningkat menjadi $81,82 \%$ pada siklus III. Apabila digambarkan dalam sebuah grafik, maka akan Nampak sebagai berikut:

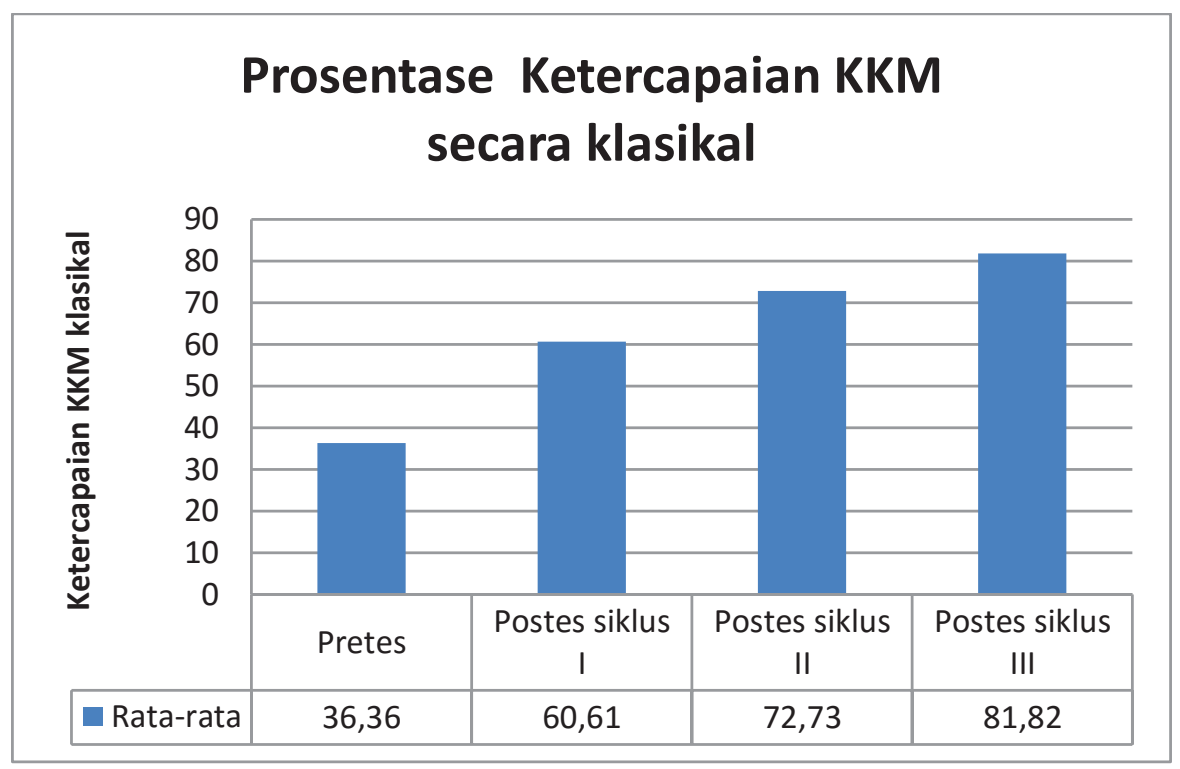

Gambar 2.2

Grafik peningkatan prosentase ketercapaian KKM secara klasikal

Berdasarkan analisis data yang di peroleh selama observasi yang dilakukan di dalam penerapan metode hypnoteaching yang dilaksanakan di kelas VII C SMP Negeri 1 Limbangan ada beberapa sisi kelebihan dan kelemahan pembelajaran yang menggunakan metode hypnoteaching. Di antara kelebihannya adalah (1). Kegiatan proses belajar mengajar terjadi lebih baik karena adanya interaktif yang bagus. (2) Proses pembelajaran lebih aktif karena banyak menggunakan simbol-simbol dan gerakan-gerakan motorik anggota tubuh, sehingga bisa melayani semua siswa dengan gaya belajar yang berbeda. (3). Peserta didik menjadi lebih mudah untuk menguasai materi pelakaran. (4) Peserta didik dapat dengan mudah menguasai materi, karena termotivasi lebih untuk belajar. (4). Peserta didik lebih bisa berfikir imajninatif dan kreatif. (5). Perhatian peserta didik akan tersedot penuh terhadap materi. 
Akan tetapi model pembelajaran dengan menggunakan metode hypnoteaching atas dasar temuan fakta dilapangan didapatkan bebarapa kelemahan yaitu:(1). Pada awal penerapan diperlukan kegiatan pembimbingan dari guru untuk melaksanakan kegiatan visualisasi dan afirmasi (2). Waktu yang dibutuhkan lebih lama dari pelajaran biasa, karena membutuhkan waktu untuk konsentrasi dan penurunan gelombang otak. (3) membutuhkan peralatan lain sebagai pendukung, seperti alat pemutar musik dan musik yang lembut dan sebagainya. (4). Apabila ada gangguan di tengah proses pembelajaran biasanya konsentrasi dan perhatian siswa mudah buyar, sehingga memerlukan pengulangan. (5) Guru harus lebih aktif memberikan sugesti yang positif dengan kalimat-kalimat yang mengena.

\section{KESIMPULAN}

Berdasarkan pembahasan yang telah penulis paparkan diatas, maka dapat diambil kesimpulan bahwa pada siklus yang ketiga, terjadi peningkatan prestasi belajar PAI yang signifikan. Peningkatan prestasi belajar yang signifikan itu bisa di lihat dari peningkatan rata-rata hasil belajar siswa dari siklus ke-2. Hasil belajar pada siklus II hanya 76,79, kemudian meningkat drastis pada siklus III menjadi 78,94, yang berarti terjadi peningkatan sebesar 8,88 dari pretes. Secara umum bisa dikatakan bahwa terjadi peningkatan ratarata hasil belajar siswa kelas VIIC SMPN 1 Limbangan, setelah menggunakan metode hypnoteaching. Sedangkan kenaikan ketercapaian KKM secara klasikal adalah dari $36,36 \%$ pada saat pretes menjadi $81,82 \%$ pada saat siklus terakhir.

Dengan begitu dapat disimpulkan bahwa pada siklus III telah terjadi peningkatan prestasi belajar PAI yang signifikan, sehingga metode hypnoteaching dapat dibakukan menjadi sebuah model pembelajaran untuk meningkatkan prestasi belajar PAI dengan tindakan sebagai berikut : a. Melakukan afirmasi, dengan cara mengucapkan yel-yel yang melibatkan gerakan tubuh dan emosi dari peserta didik, b. Melakukan visualisasi, dengan cara menghadirkan sesuatu dalam alam bayangan kita disertai gerakan menyentuh anggota tubuh, c. Melakukan repetisi dengan cara tutor sebaya dalam sebuah kelompok, seperti permainan kata berkait, d. Mengajak siswa bersyukur atas ilmu yang telah diberikan Allah dengan suara yang lembut dan menyentuh hati. 


\section{DAFTAR PUSTAKA}

Almatin, MD. Isma. (2010). Dahsyatnya hypnosis learning, untuk guru dan orang tua. Yogyakarta: Pustaka Widyatama

Arends, Richard I. (2007). Learning to Teach, Sevent Edition. New York: McGraw Hill Companies, Inc.

Arifin, HM. (2003). Ilmu pendidikan islam, tinjauan teoritis dan praktis berdasarkan pendekatan interdisipliner, Jakarta: Bumi Aksara . (1996). Filsafat pendidikan islam, Jakarta : Bumi Aksara

Arikunto, Suharsimi. (1998). Manajemen penelitian, Jakarta : Rieneka Cipta. . (2007). Penelitian tindakan kelas. Jakarta: Bumi Aksara.

Armai, Arif. (2002). Pengantar ilmu dan methodologi pendidikan islam, Jakarta: Ciputat Press

Arti, Yuni. (2011), Upaya meningkatkan minat siswa pada pembelajaran IPA fisika dengan metode hypnoteaching menggunakan pendekatan kontekstual pada siswa kelas VIID Mts.Al-Asror Patemon Kec. Gunungpati Semarang Tahun Pelajaran 2010/2011: http://lpf2011. ikippgrismg.ac.id/downlot.php?full_paper=files/...doc. Download pada hari Rabu, 3 Agustus 2011, Jam 12.10 WIB.

Asmani, Jamal Ma'mur. (2001). Tips menjadi guru inspiratif, kreatif dan inovatif, Yogyakarta: Diva Press

Baharuddin dan Esa Nur Ayuni. (2009). Teori belajar dan pembelajaran, Yogyakarta: Arruz Media

Budiman, M. Nasir. (2001). Pendidikan dalam perspektif Al Qur'an, Jakarta : Madani Press

Creswell, John W. (2008). Educational Reseacrh, Planing, Conducting, and Evaluating Quantitative and Qualitative Reseach. Third Edition. Lincoln: University of Nebraska

Danim, Sudarwan. (2002). Inovasi pendidikan dalam upaya peningkatan profesionalisme tenaga kependidikan, Bandung : Pustaka Setia,

Daryanto. (2005). Evaluasi pendidikan. Jakarta: Rineka Cipta.

Davehard. (2011). Pembelajaran hypnoteaching. http://davehard.wordpress. com/ pembelajaran-hypnoteaching/. di download pada hari Rabu, 27 Juli 2011, jam 07. 53 WIB 
Depdikbud, Indonesia. (1989). Kamus besar bahasa indonesia. Jakarta: Balai Pustaka.

Deporter, Bobbi dan Mike Hernacki. (2002). Quantum learning, unleashing the genius in you. Terj. Alwiyah Abdurrahman. Bandung: Kaifa

Fathuddin, Asef Umar. (2009). Menjadi guru favorit. Yogyakarta: DIVA Press.

Gunawan. (2011). Hypnoteaching. http://gunawancogan.blogspot.com /2011/05/ hypnoteaching.htm1, Download hari Rabu, 3 Agustus 2011, jam 12.40

Gunawan, Adi W. (2010). Hypnotheraphy for children, cara mudah dan efektif menerapi anak. Jakarta: Gramedia pustaka utama

Hakim, Andri. (2010). Hypnosis in teaching: cara dahsyat mendidik dan mengajar. Jakarta: Visimedia

Jaya, Novian Triwidia. (2010). Hypnoteaching: bukan sekedar mengajar. Bekasi : D-Brain:

Muhaimin dan Abdul Mujib. (1993). Pemikiran pendidikan islam. Bandung: Trigenda Kaiya.

Muhajir, Noeng (1989). Metodologi penelitian kualitatif, Surakarta : Rake Surasin,.

Muijs, Daniel dan David Reynolds. (2008). Efective teaching : teori dan aplikasi. Yogyakarta: Pustaka Pelajar.

Mulyasa, E. (2009). Praktik penelitian tindakan kelas. Bandung: Remaja Rosdakarya.

. (2003). Manajemen berbasis sekolah. Bandung : Remaja Rosdakarya.

. (2004). Menjadi kepala sekolah profesional dalam konteks menyukseskan MBS dan KBK. Bandung : Remaja Rosdakarya.

Nasution, Mursell S. (1995). Mengajar dengan sukses: successful teaching. Jakarta: Bumi Aksara.

Nasution, S. (1996) Metode research, Jakarta : Bumi Aksara.

Nirmala, Oktastika Badai. (2011).Hypnoteaching2, http://www.mediasugesti. blogspot.com, di download pada hari Rabu, 27 Juli 2011, jam 08.02 WIB.

Noer, Muhammad. (2010). Hypnoteaching for success learning. Yogyakarta: pedagogia 
Pangayoman, Samudra. (2010). 3 hari menjadi master hipnotis paling andal. Yogyakarta: Pustaka Araska Media Utama

Peraturan Menteri Pendidikan Nasional Nomor : 22 tahun 2006 tentang Standar Isi

Poerwodarminto. (1976). W.J.S. Kamus umum bahasa Indonesia, Jakarta: Balai Pustaka.

Purwanto, (2010). Evaluasi hasil belajar. Yogyakarta: Pustaka Pelajar . (2007). Instrumen penelitian sosial dan pendidikan. Yogyakarta: Pustaka Pelajar , (2010). Statistika untuk penelitian, Surakarta: Pasca Sarjana STAIN Surakarta.

Purwanto, M. Ngalim. (1998). Administrasi dan supervisi pendidikan, Bandung : Remaja Rosdakarya.

Ramayulis. (2001). Metodologi pengajaran agama islam, Jakarta: Kalam Mulia

Sari, Farida Yunita \& Mukhlis. (2011). Hypnolearning: 1 menit bikin gila belajar \& siap jadi juara. Jakarta: Visimedia

Shichida, Makoto. (2010). The mystery of the right brain. Mengungkap misteri otak kanan untuk membuat anak jadi genius. Terjemah (Femi Olivia). Jakarta: PT. Elex Media Komputindo

Sudjana, Nana dan Ibrahim. (1989). Penelitian dan penilaian pendidikan. Bandung: Sinar Baru.

Sugiyono. (2009). Metode penelitian kuantitatif, kualitatif dan $R \& D$. Bandung: Albeta.

Sulhan, Najib. (2010). Pembangunan karakter pada anak, manajemen pembelajaran guru menuju sekolah efektif. Surabaya: SIC

Supriadi, Dedi. (2000). Mengangkat citra dan martabat guru, Surakarta : Adicita Karya Nusa

Suprijono, Agus. (2010). Cooperative learning: teori dan aplikasi PAIKEM. Yogyakarta: Pustaka Pelajar.

Suryosubroto, B. (1997). Proses belajar mengajar di sekolahan. Jakarta: Rineka Cipta. . (2009). Psikologi belajar. Jakarta: PT Rajagrafindo Persada. 
Sutrisno. (2008). Pendidikan islam yang menghidupkan. Yogyakarta: Kota kembang

Syukur, Freddy Faldi. (2010). Menjadi guru dahsyat, guru yang memikat melalui pendekatan teknologi pikiran bawah sadar Hypnoteaching dan NLP. Bandung: Simbiosa rekatama media

Tafsir, Ahmad. (1992). Ilmu pendidikan dalam perspektif islam, Bandung: Remaja Rosda Karya

Tim Penyusun, (2001). Kamus besar bahasa indonesia, Jakarta: Balai Pustaka.

Undang Undang No. 20 Tahun 2003 Pasal 1 Tentang Sistem Pendidikan Nasional (SISDIKNAS) Dan Penjelasannya.

Uno, Hamzah B. (2007). Profesi Kependidikan: problema, solusi, dan reformasi pendidikan di indonesia. Jakarta: Bumi Aksara.

Usman, Uzer. (1995). Menjadi guru profesional. Bandung: remaja rosdakarya.

Wiriatmaja, Rochiati. (2006). Metode penelitian tindakan kelas: untuk meningkatkan kinerja guru dan dosen. Bandung: Remaja Rosdakarya 